\title{
The forms of occurrence and geochemistry of sulfides in hard coal deposits of the Libiąż Beds in the Upper Silesian Coal Basin, Southern Poland
}

\author{
Barbara Bielowicz, Jacek Misiak \\ AGH University of Science and Technology; Faculty of Geology, Geophysics and Environment Protection; \\ al. A. Mickiewicza 30,30-059 Krakow, Poland; e-mail:bbiel@agh.edu.pl \\ (C) 2017 Authors. This is an open access publication, which can be used, distributed and reproduced in any medium according \\ to the Creative Commons CC-BY 4.0 License requiring that the original work has been properly cited.
}

Received: 3.04.2017; accepted: 4.07.2017

\begin{abstract}
Samples of coal from the eastern part of the Upper Silesian Coal Basin, between Jaworzno and Libiąż, were collected from test boreholes and underground excavations in the Janina Coal Mine, southwest Poland. The No. 111-119 hard coal seams are in the upper part of the Cracow Sandstone Series (the Libiąż Beds, Westphalian D). Macroscopically, iron sulfides (pyrite and marcasite) found in hard coal seams are usually in vein and impregnation forms. On the basis of microscopic observations, the following forms of iron sulfides occurrence in the studied coal were observed: framboidal pyrite, euhedral crystals, skeletal and massive vein forms, or pocket-like (impregnation) forms. On the basis of SEM-EDS analysis and X-ray diffraction it can be stated that the iron sulfides observed in coal are a mixture of pyrite and marcasite. WDS analysis in the micro area revealed the chemical composition of sulfides. The iron sulfides contain admixtures of $\mathrm{Pb}, \mathrm{Hg}, \mathrm{Zn}, \mathrm{Cu}, \mathrm{Au}, \mathrm{Ag}, \mathrm{Sb}, \mathrm{Co}$, and $\mathrm{Ni}$. There was no As and $\mathrm{Cd}$ found in the examined minerals. It has been shown that the tested iron sulfides do not include significant admixtures. There is only a slight enrichment in lead in the vein forms of sulfides. In addition to the iron sulfides, individual inclusions of galena and sphalerite within the pyrite and marcasite have been observed. When it comes to iron sulfides in the vicinity of the crystallized galena, no lead $(\mathrm{Pb})$ in the pyrites can be observed.
\end{abstract}

Keywords: coal, sulfides, pyrite, marcasite

\section{INTRODUCTION}

Hard coal is one of the most important energy sources in the world. However, in light of the agreement signed at the Paris climate conference, a new approach to the problem of coal use and its consequences for the environment is needed (United Nations 2015). The harmful toxic compounds present in coal and ash - in addition to $\mathrm{CO}_{2}$ emissions from coal combustion - are particularly dangerous (e.g., As, $\mathrm{Pb}, \mathrm{Hg}, \mathrm{Co}$ ). The carrier of these pollutants is usually the mineral matter. The inorganic matter in coal is usually present in the form of minerals, other aggregations in the form of veins or macroscopically visible layers or dispersed throughout the coal macerals (Ward 2002). The size of individual mineral grains varies largely in the range from less than one micrometer to tens or hundreds of micrometers (Taylor et al. 1998).

Minerals found in coal are divided into three groups on the basis of their origin (Stach et al. 1975): (1) minerals from the original plants; (2) minerals formed in the initial stage of the coalification process or introduced into the peat by water and wind, and (3) minerals deposited 
in the second phase of the coalification process, after consolidation of coal, by ascending or descending solutions in cracks, fissures, and cavities or by alteration of primarily deposited minerals. The most common minerals in coal include quartz, clay minerals, feldspars, carbonates, sulfide minerals, and sulfates. Therefore, sulfides can be categorized as either of syngenetic (primary), early-diagenetic, or epigenetic (secondary) origin (Stach et al. 1975). Sulfides in coal are mainly represented by pyrite $\left(\mathrm{FeS}_{2}\right)$, marcasite $\left(\mathrm{FeS}_{2}\right)$, pyrrhotite $\left(\mathrm{Fe}_{(1-x)} \mathrm{S}\right)$, sphalerite $(\mathrm{ZnS})$, galena $(\mathrm{PbS})$, and chalcopyrite $\left(\mathrm{FeCuS}_{2}\right)$. Pyrite is a common mineral in many coal seams, especially those of Carboniferous age, in Europe and North America (Harvey \& Ruch 1986, Demchuk 1992).

Many previous studies (Balme 1956, Wiese \& Fife 1986, Frankie \& Hower 1987, Harvey \& DeMaris 1987, Renton \& Bird 1991, Kwiecińska et al. 1992, Baruah 1995, Turner \& Richardson 2004, Dai et al. 2006, 2010,Elswick et al. 2007, Widodo et al. 2010, Chou 2012) have described the characteristics, type, morphology, genesis, and distribution of pyrite in coal seams from different deposits. In Poland, the issue of sulfides in coal has been discussed by Kucha \& Lipiarski (1988) and Sawłowicz (2000).

Hazardous air pollutants, released during coal utilization, are common in sulfide minerals occurring in coal (Weise et al. 1990, Spears et al. 1999, Dai et al. 2003, Yudovich \& Ketris 2005, Ketris \& Yudovich 2009, Diehl et al. 2012, Kolker 2012, Bielowicz 2013, KokowskaPawłowska 2014, Adamczyk et al. 2015). According to the data of the National Centre for Emissions Management approved by the Ministry of Environment, the total emission of main air pollutants in Poland in 2013 (in thousand tons) was as follows: sulfur dioxide -847 , nitrogen oxides - 798, carbon dioxide - 322,900, carbon oxide 2876, volatile non-methane organic compounds - 919, ammonia - 263, and particulates - 407 (Environment 2015).

This study focuses on the sulfides occurring in Polish hard coal deposits with an emphasis on the characteristics of forms of occurrence of sulfides on both macroscopic and microscopic scale and on the chemical analysis in the micro area.

\section{LOCATION AND COAL QUALITY}

The study was conducted on the No. 111-119 seams from the Libiąż area, belonging to the Cracow Sandstone Series in the UpperSilesianCoalBasin. Samples of coal from the eastern part of the Upper Silesian Coal Basin, between Jaworzno and Libiąż (Fig. 1), were collected from test boreholes and underground excavations of the Janina Coal Mine. The mining area of the Janina Coal Mine is located approximately $50 \mathrm{~km}$ west of Krakow. The Janina Coal Mine is located in the eastern part of the main basin of the UpperSilesianCoalBasin. The drillings have shown that the geological structure of the deposit exploited in the Janina mine contains Carboniferous, Triassic, Miocene, and Quaternary formations. The exploited coal varies between lowrank coal (subbituminous coal) and medium rank coal (parabituminous coal, medium rank D), occurring within the Cracow Sandstone Series in Libiąż and Łaziska Beds (Fig. 2). The No. 111-119 hard coal seams, which were also examined, stratigraphically belong to the upper part of the Cracow Sandstone Series (The Libiąż Beds).The Libiąż Beds constitute the uppermost part of Carboniferous formations of the UpperSilesianCoalBasin (Dembowski 1972). The thickness of the discussed layers varies and in the central part (Fig. 1) it reaches up to $400 \mathrm{~m}$. This area is dominated by conglomerates and sandstones, while the thin layers of mudstones and claystones are generally over- and underlying the coal seams. The share of sandstones in the profile ranges from $70 \%$ to $80 \%$. The Libiąż Beds include eight to nine coal seams, of which four - the No. 116-119 - are of industrial importance, while their total thickness varies from $5 \mathrm{~m}$ up to $6.3 \mathrm{~m}$ (Jureczka et al. 1995). The main technological parameters in the studied coal seams are as follows: average ash content $\left(\mathrm{A}^{\text {ar }}\right)-10.40 \%$ (in the range from $6.4-18 \%$ ), average sulfur content $\mathrm{S}_{t}{ }^{\mathrm{d}}-1.7 \%$ (ranging from $0.6 \%$ to $2.5 \%$ ), average moisture $\mathrm{M}_{\mathrm{t}}^{\text {ar }}-19.3 \%$ (in the range from $19 \%$ to $21 \%$ ), average net calorific value $\mathrm{NCV}-28.71 \mathrm{MJ} / \mathrm{kg}$, and average vitrinite reflectance $\mathrm{R}_{\mathrm{o}}$ - about $0.5 \%$. These seams are characterized by relatively high sulfur content, which, depending on a seam, ranges from $1.5 \%$ to $2.5 \%$ (Górecki 1985). 


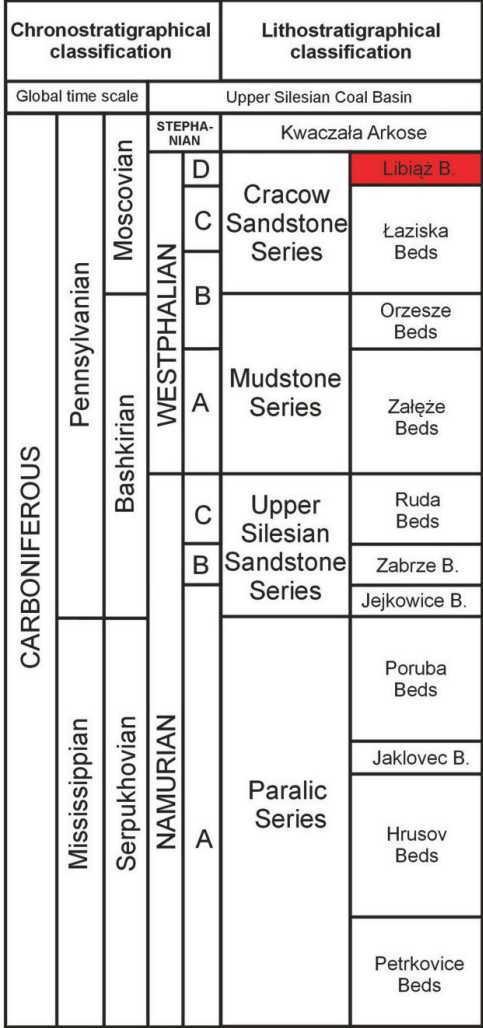

- examined sector

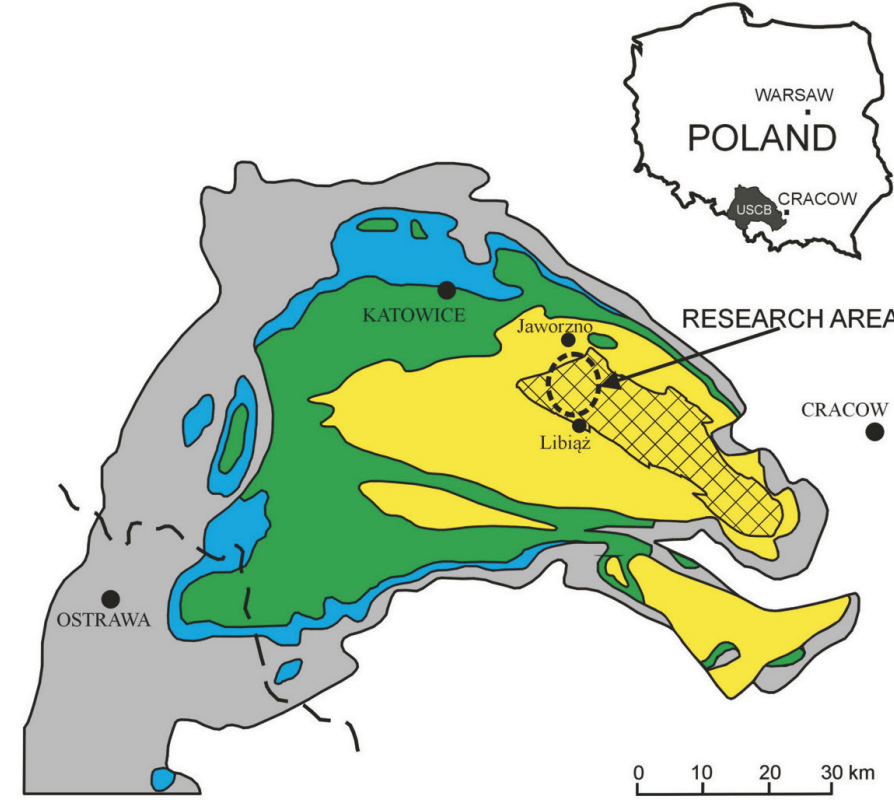

XXX Cracow Sandstone Series - Libiąż Beds

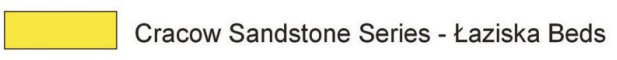

Mudstone Series

Upper Silesia Sandstone Series

Paralic Series

Fig. 1. The geological sketch-map of the Upper Silesian Coal Basin (USCB) in Poland (Jureczka et al. 1995) showing the location of the research area and simplified lithostratigraphic subdivision (Zdanowski \& Żakowa 1995, modified) of the Carboniferous system of the USCB

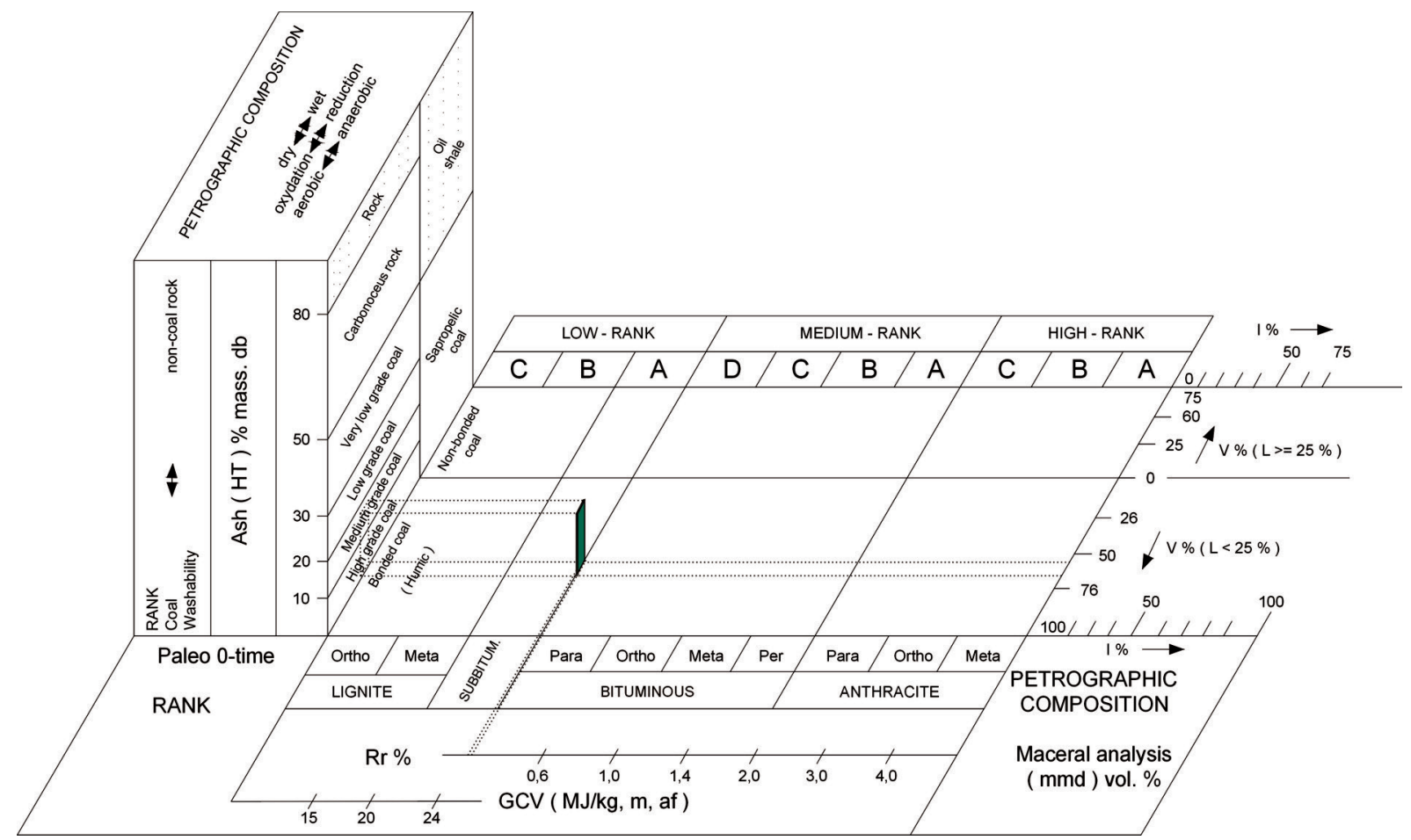

Fig. 2. Location of coal from the Janina mine in the UNECE International Classification of In-Seam Coals (UNECE 1998) 


\section{SAMPLING AND}

\section{ANALYTICAL METHODS}

The stratigraphic sections containing the coal seams were measured, which was followed by the collection of lump samples. Six coal seams were profiled (No. 111, 112, 113, 115, 116/2, 119/2), from which 93 samples were collected. The collected samples were described macroscopically. The macroscopic analysis has shown that sulfides occur in 37 coal samples. Then, the collected samples were grinded to grain size $<1 \mathrm{~mm}$ and used as material for polished sections made according to PN-ISO 7404-2:2005. Petrographic examination was performed under white reflected light and blue light excitation using an Zeiss Opton microscope according to PN-ISO 7404-3:2001 standard. Reflectance of vitrinite were carried out to PN-ISO 7404-5:2002. Maceral nomenclature for the vitrinite and inertinite maceral groups is according to the International Committee for Coal and Organic Petrology (Stach et al 1982; ICCP, 1998, 2001). Maceral nomenclature for the liptinite group is according to Taylor et al. (1998). The maceral group and sulfides content analysis were performed with the use of 500 equally spaced points on the surface of the polished sections. Five coal seams with the most diverse forms of sulfides were selected for the wavelength dispersive X-ray spectrometer (WDS) analysis. The coal samples were tested using a JEOL JXA-8230 superprobe electron microprobe, used to analyze the chemical composition of solids in the micro area $(<1 \mu \mathrm{m})$. The elemental composition analysis in the micro area was performed using an energy dispersive spectrometer (EDS) X-ray microprobe for all elements from boron to uranium. The quantitative analysis of the elemental composition using the secondary wavelength-dispersive $\mathrm{X}$-ray spectroscopy (WDS) was performed with five spectrometers. The WDS analysis was performed with a $20 \mathrm{nA}$ current and an accelerating voltage of $20 \mathrm{kV}$. Counting times of 20 seconds on peak and 10 seconds on both (+) and (-) backgrounds were used. The following standards and lines were used: $\mathrm{HgTe}, \mathrm{PbS}, \mathrm{CdS}, \mathrm{FeS}_{2}, \mathrm{Au}, \mathrm{Co}$, $\mathrm{Sb}_{2} \mathrm{~S}_{3}, \mathrm{Ag}, \mathrm{Ni}, \mathrm{ZnS}$, and GaAs. The pictures in the micro area and the EDS analysis were taken using a FEI Quanta 200 FEG Field Emission Scanning Electron Microscope.

The qualitative determination of the mineral composition of sulfides was carried out with the $\mathrm{X}$-ray diffraction (Debye-Scherrer method) on the $119 / 2$ sample. The diffractograms of sulfides from the sample were recorded with a RIGAKU MiniFlex X-ray diffractometer using the following parameters: $\mathrm{Cu}_{\mathrm{K \alpha}}$ radiation, reflective graphite monochromator, x-ray tube voltage $30 \mathrm{kV}, X$-ray tube current $20 \mathrm{~mA}$, a step-by-step record: step = $0.05^{\circ} 2 \Theta$, counting time $1 \mathrm{sec} / \mathrm{step}$.

The d-spacings obtained from diffractograms were used to identify the mineral phases included in the tested samples using data from the ICDD (ICDD 2017) and XRAYAN software.

\section{RESULTS AND DISCUSSION}

\section{Petrographic analysis}

The petrographic analysis of the No. 111-116/2 seams specifies the maceral and sulfide content in relation to the thickness of the whole coal seam. In case of the No. 119/2 seam, the analysis included samples with macroscopically visible sulfides. The results are presented in Table 1.

Table 1

Petrographic composition of coal from the Janina Coal Mine

\begin{tabular}{|c|c|c|c|c|c|c|}
\hline \multirow{3}{*}{ Seam No. } & \multirow{2}{*}{ Thickness } & \multirow{2}{*}{$\begin{array}{l}\text { Vitrinite } \\
\text { group }\end{array}$} & \multirow{2}{*}{$\begin{array}{c}\text { Inertinite } \\
\text { group }\end{array}$} & \multirow{2}{*}{$\begin{array}{l}\text { Liptinite } \\
\text { group }\end{array}$} & \multicolumn{2}{|c|}{ Mineral matter } \\
\hline & & & & & sulfides & others \\
\hline & $\mathbf{m}$ & \multicolumn{5}{|c|}{$\%$} \\
\hline 111 & 1.16 & 69.2 & 18.4 & 7.9 & 1.7 & 2.8 \\
\hline 112 & 0.59 & 67.3 & 17.4 & 12.2 & 2.8 & 0.3 \\
\hline 113 & 1.01 & 64.6 & 20.1 & 9.9 & 4.5 & 0.9 \\
\hline 115 & 1.41 & 71.1 & 16.3 & 6.2 & 5.2 & 1.2 \\
\hline $116 / 2$ & 1.74 & 59.5 & 27.1 & 12.1 & 0.9 & 0.4 \\
\hline $119 / 2$ & 3.46 & \multicolumn{5}{|c|}{ Point samples } \\
\hline
\end{tabular}


The distribution of maceral groups in coal from the tested coal seams is as follows: the vitrinite group comprises $59.5-71.1 \%$, the inertinite group $16.3-27.1 \%$, and the liptinite group $6.2-12.2 \%$. The percentage of sulfides in the tested coal seams ranges $0.9 \%-5.2 \%$. A detailed petrographic analysis of the petrographic composition of the No. 116/2 seam, albeitina different location, has been done by Misiak (2011).

Macroscopically, iron sulfides (pyrite, marcasite) found in hard coal seams in the Libiąż Beds occur very frequently and in different forms. These are usually vein, pocket-like (impregnation) forms, massive, and dispersed forms. The presence or absence of bireflection is an undisputed determinant used to differentiate pyrite from marcasite (Uytenbogaardt \& Burke 1985). The varying proportions of pyrite and marcasite depend on the form of their occurrence. Pyrite and marcasite in vein forms are often interlayered. On the other hand, pyrite can usually be found in impregnation and framboidal forms.

Vein forms cross cut across bedding, their horizontal size ranges from less than $1 \mathrm{~mm}$ to several mm (Fig. 3A, B). Individual veins occur very rarely. Usually two, and up to ten, veins occur next to each other; the width of such zones is up to several centimeters, while the length is highly variable,ranging from a few millimeters to several decimeters.

Veins of large lengths can be found in coal containing various lithotypes, such as vitrain, durain, clarain, and fusain, interlaying each other (Fig. 3A). Veins of short lengths from a few to several millimeters usually occur in contraction fissures in vitrain. Usually, veins occur in skeletal forms (Fig. 3A), which means that they underwent numerous fissions; the main vein of a thickness of a few millimeters is often accompanied by a number of thin veins of different lengths and directions. Massive forms (Fig. 3B), which are thicker than skeletal forms, occur less frequently and are usually not accompanied by thin veins. These occur in areas where the aforementioned veins go through the vitrain layers or can be found in contraction fissures. Veins of horizontal orientation (Fig. 3C) are usually connected with vertical fissures and are developed in the contraction fissures in vitrain.
Pocket-like forms (Fig. 3D, E, F) are to $3 \mathrm{~mm}$ impregnations of iron sulfides within fusain. The degree of filling of voids with sulfides in fusain is different and ranges from several to $100 \%$. Pocketlike forms containing sulfides are often surrounded by a halo of thin veins.

Dispersed sulfides in the tested coal are relatively rare; because of their dimensions, theyare usually macroscopically "invisible". However, they are macroscopically visible (Fig. 3G) when in high concentrations - usually in the form of polyframboids. Such forms of pyrite with sizes ranging from below $1 \mathrm{~mm}$ to several $\mathrm{mm}$ have been observed in vitrain, durain, and fusain.

On the basis of microscopic observations, several forms of the occurrence of iron sulfides in the studied coal can be distinguished. Framboidal pyrite occurs relatively rarely. Out of the six tested coal seams, its presence has been found in only a few sections of a few centimeters length, where the petrographic composition of coal has revealed the occurrence of alginite. Single framboids or their concentrations can be found in collotelinite, collodetrinite, and fusinite. The size of individual framboids varies in the range from $10 \mu \mathrm{m}$ up to $20 \mu \mathrm{m}$. In the case of high concentrations of framboids in one place, they form polyframboidal aggregates of sizes up to $200 \mu \mathrm{m}$ (Fig. 4A). Framboidal pyrite is an early diagenetic form of pyrite (Wilkin \& Barnes 1997), is categorized as syngenetic (Dai et al. 2007) and originates from pyritization by sulfur bacteria (Casagrande et al. 1977, Kortenski \& Kostowa 1996, Querol et al. 1989, Renton \& Cecil 1979).

Pyrite in the euhedral form of crystals (Fig 4B) is rare in the studied coal and has been detected in only a few locations within massive pyrite. The size of single crystals ranges from 30 up to $400 \mu \mathrm{m}$. However, these are not typical euhedral forms with well-developed crystals usually in the dispersed form, as described by Kortenski \& Kostova (1996) and Querol et al. (1989).

Iron sulfides in the vein form cut through the coal seams in different directions; usually these are not single veins, as they typically form a network of cracks. In collotelinite (Fig. 4C), the main veins intersect all layers of this maceral while accompanying veins fill the contraction fissures. Veins continuing in areas made of other macerals 
(Fig. 4D), in this case collodetrinite binding liptinite group macerals (mainly sporinite), are of different orientations and smaller. Such forms of iron sulfides, occurring in fractures and cleats in coal, are referred to as "infiltrational pyrite" by Kortenski \& Kostova (1996).
Iron sulfides form impregnation forms, typically associated with the positions of fusinite occurrence. Sulfides occur in voids and fill them in varying degrees from $1 \%$ up to $100 \%$. An example of the partial filling of fusinite cells with sulfides is presents in Figure 4E.
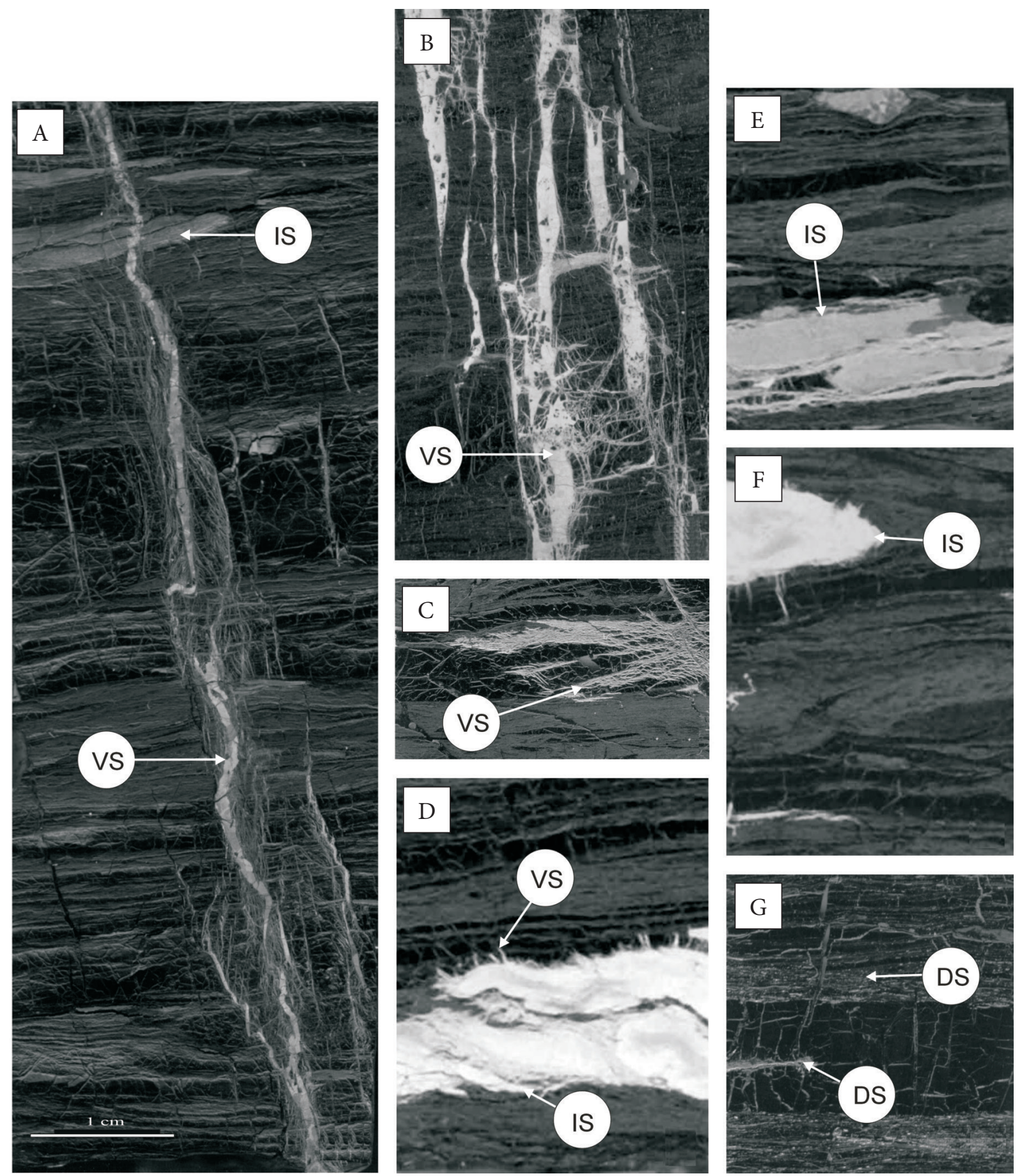

Fig. 3. Macroscopic forms of occurrence of iron sulfides (pyrite, marcasite) in the hard coal seams of the Libiaż Beds: A) skeletal/vein forms (VS) slanted to the bedding of coal; B) massive forms, slanted to the bedding of coal; C) vein forms parallel to the bedding of coal; D), E), F) pocket-like (impregnation) forms (IS); G) dispersed forms (DS). Scale bar is the same for all images 

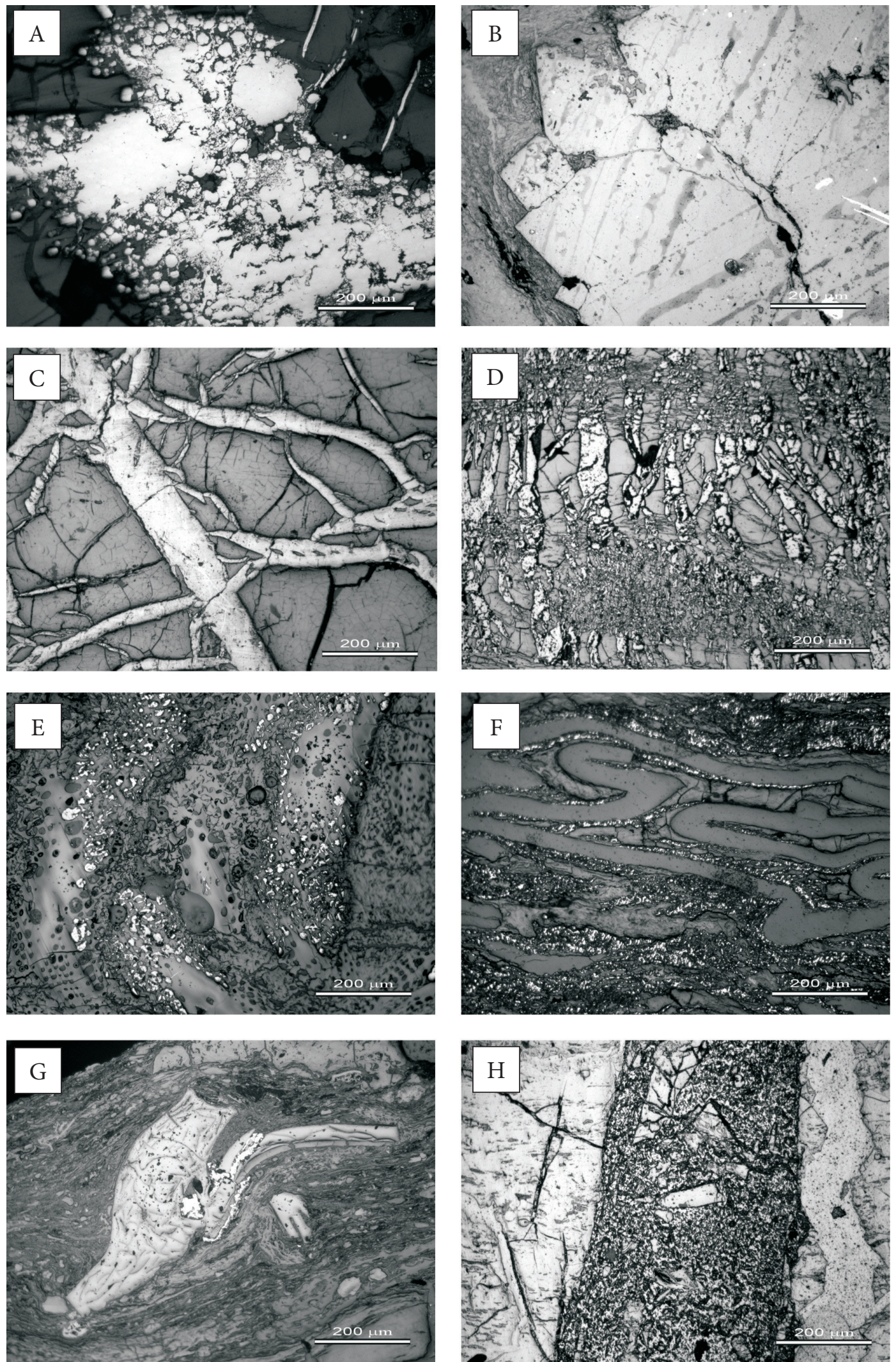

Fig. 4. Microscopic forms of occurrence of iron sulfides (pyrite, marcasite) in the hard coal seams of the Libiaz Beds. Reflected light photomicrograph of: A) framboids and polyframboids; B) euhedral crystals and massive aggregations; $C$ ) veins in contraction fissures of collotelinite; D) veins in contraction fissures of collotelinite (middle part of the image), veins in collodetrinite with liptinite (upper and lower part of the image); E) iron sulphides in fusinite cells; F) iron sulphides in fissures around macrosporinite; $G)$ iron sulphides in secretinite voids; $H$ ) iron sulphides binding the coal breccia in the fissure 
Sometimes, the impregnations of this type take a framboidal form, but only in these sections of the profile where framboids occur in other macerals, such as collotelinite and collodetrinite. In the tested coals, the sporadic occurrence of iron sulfides in the form of impregnations around macrosporinite (Fig. 4F), funginite, and in secretinite (Fig. 4G) has been observed. Such forms of iron sulfides, whose shape depends on the shape of cell lumens and pores filled with plant debris (dead plant material), are referred to as "anhedral pyrite” by Kor tenski \& Kostova (1996). Iron sulfides may also bind coal breccia in fissures (Fig. $4 \mathrm{H}$ ).

\section{$\mathrm{X}$-ray diffraction}

The No. 119/2 sample was subjected to X-ray diffraction. The identification of some of the sulfides during microscopic examination has brought some problems related to, among others, too small dimensions of samples. The X-ray diffractogram of the analyzed sample with identified phases is shown in the Figure 5. This analysis has confirmed earlier microscopic observations of iron sulfides - represented by pyrite and marcasite - in the tested sample.

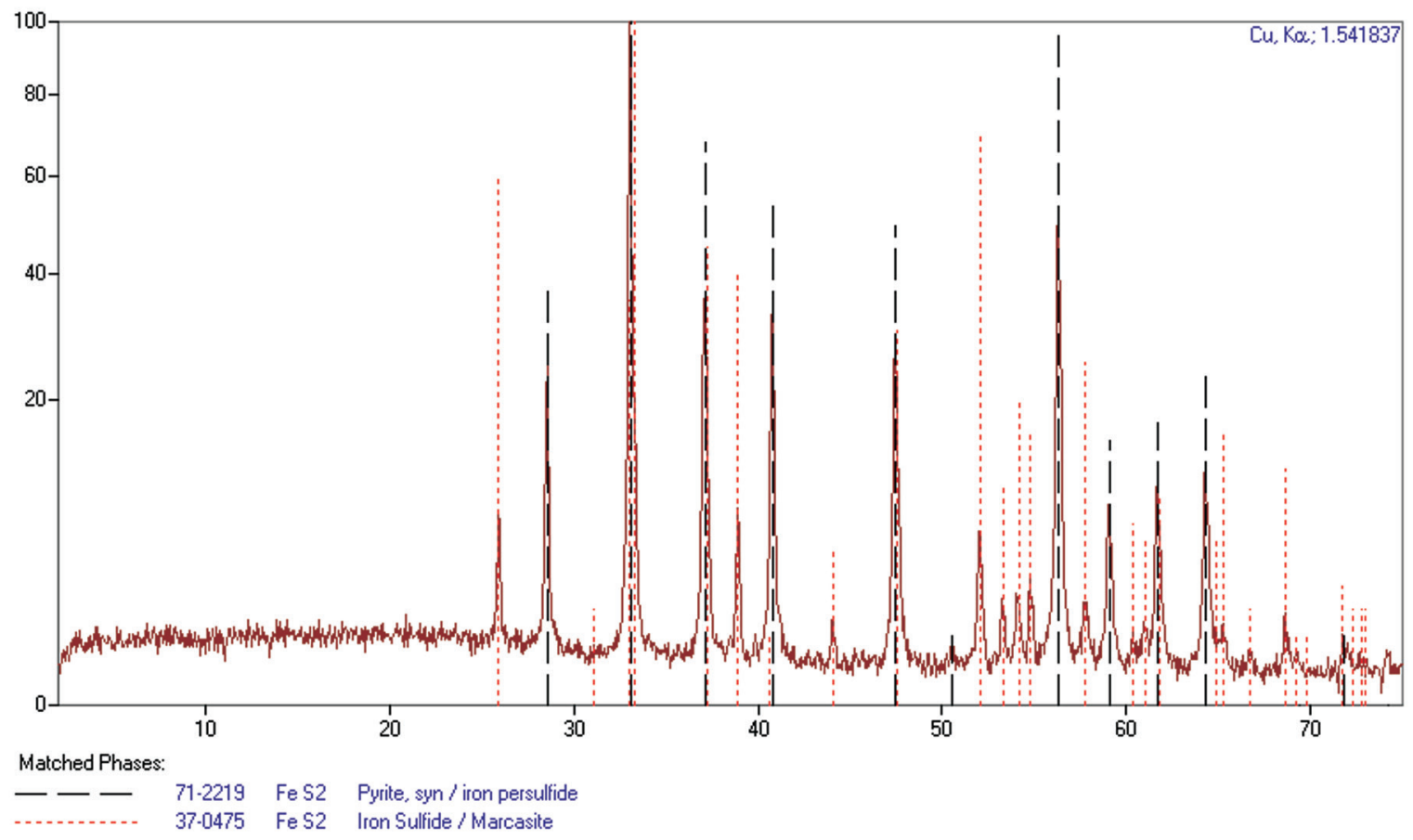

Fig. 5. X-ray diffractogram of sulfides from the coal sample No. 119/2

\section{Scanning electron microscopy with the EDS}

Scanning electron microscopy has revealed that pyrite and marcasite forming the vein formations are multigenerational. However, as observed with the EDS analysis, the aforementioned veins are made of iron sulfide of similar chemical composition, which has been shown in Figure 6 .

\section{The chemical analysis in the micro area}

The WDS analysis in the micro area revealed the chemical composition of sulfides, showing that the tested seams contain mainly iron sulfides. In addition, small amounts of galena and sphalerite can also be found. The iron sulfides also contain admixtures of $\mathrm{Pb}, \mathrm{Hg}, \mathrm{Zn}, \mathrm{Cu}, \mathrm{Au}, \mathrm{Ag}, \mathrm{Sb}, \mathrm{Co}$, and Ni. No As and Cd was found in the examined minerals. Minor differences in the chemical composition are manifested with changes of the image color.

Pure pyrite and marcasite contain $46.55 \%$ $\mathrm{Fe}$ and $53.45 \% \mathrm{~S}$. The sulfides in the tested samples ranged from $43.76 \%$ to $46.46 \% \mathrm{Fe}$ and from $50.26 \%$ to $53.87 \% \mathrm{~S}$, with mean values of $45.6 \% \mathrm{Fe}$ and $52.75 \% \mathrm{~S}$ (Tab. 2). Both iron and sulfur content in the tested minerals is poorly variable. Similar results for $\mathrm{Fe}$ and $\mathrm{S}$ content in iron sulfides from coal were obtained by Ruppert et al. (2005) and Kucha \& Lipiarski (1998). 

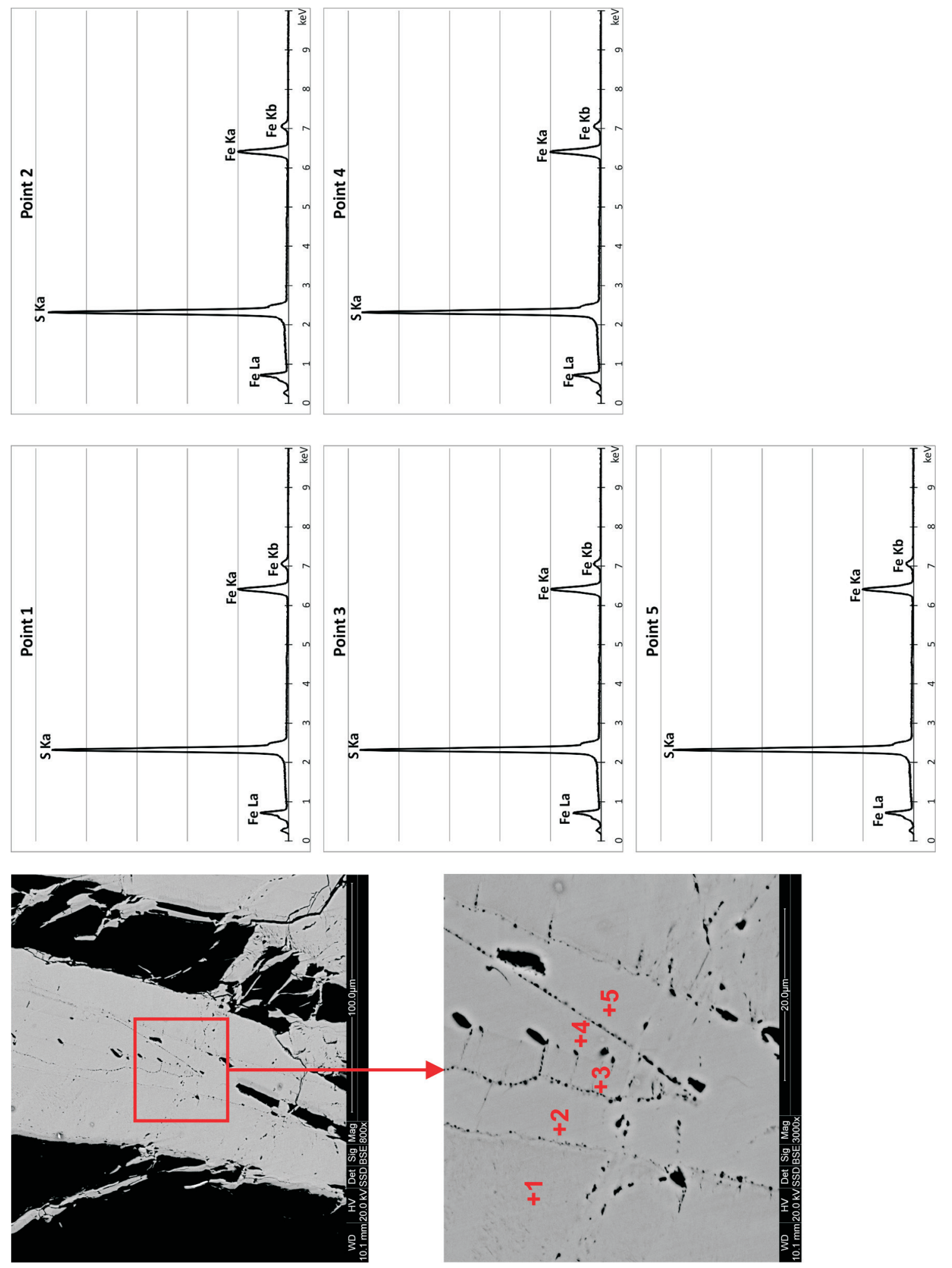


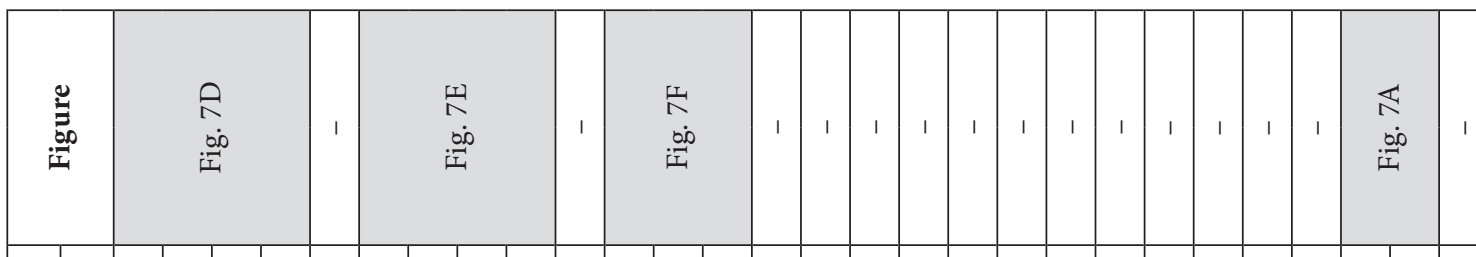

Jే ث) य

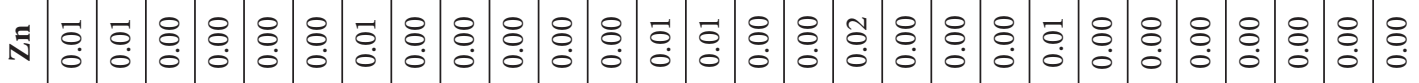
z

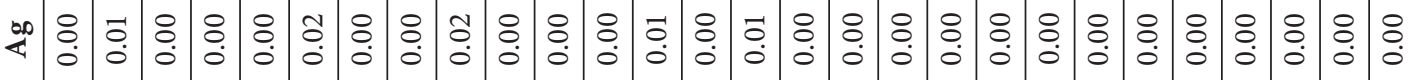
道 告

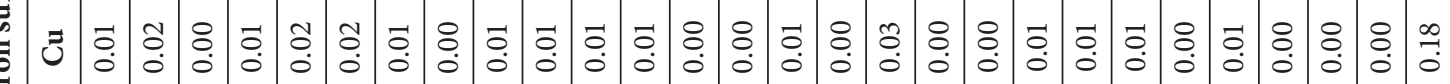
.

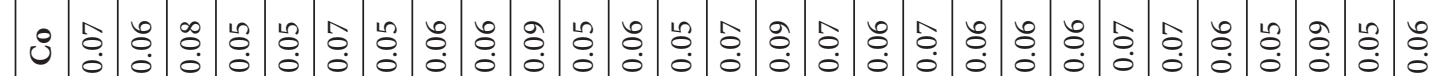

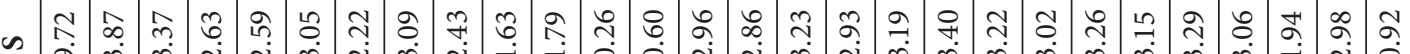
๘

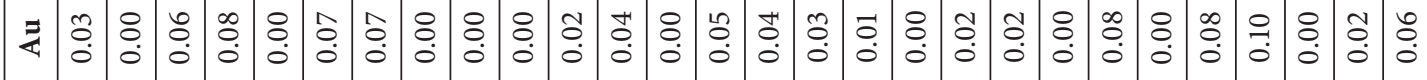
-

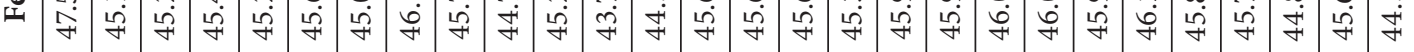
उ

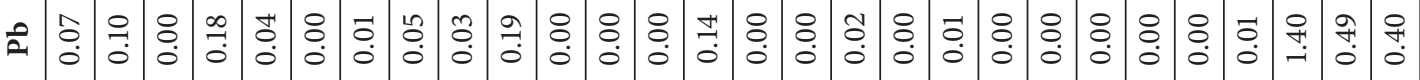
尘

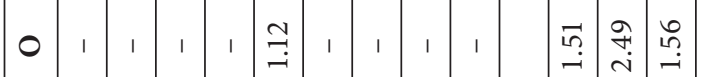

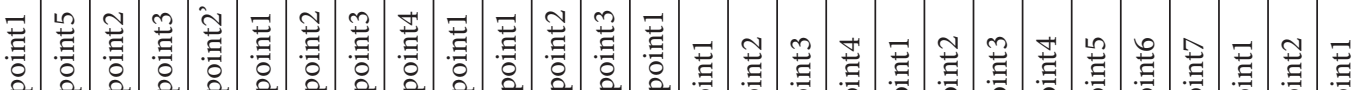
菅

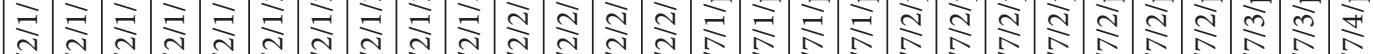
党点 


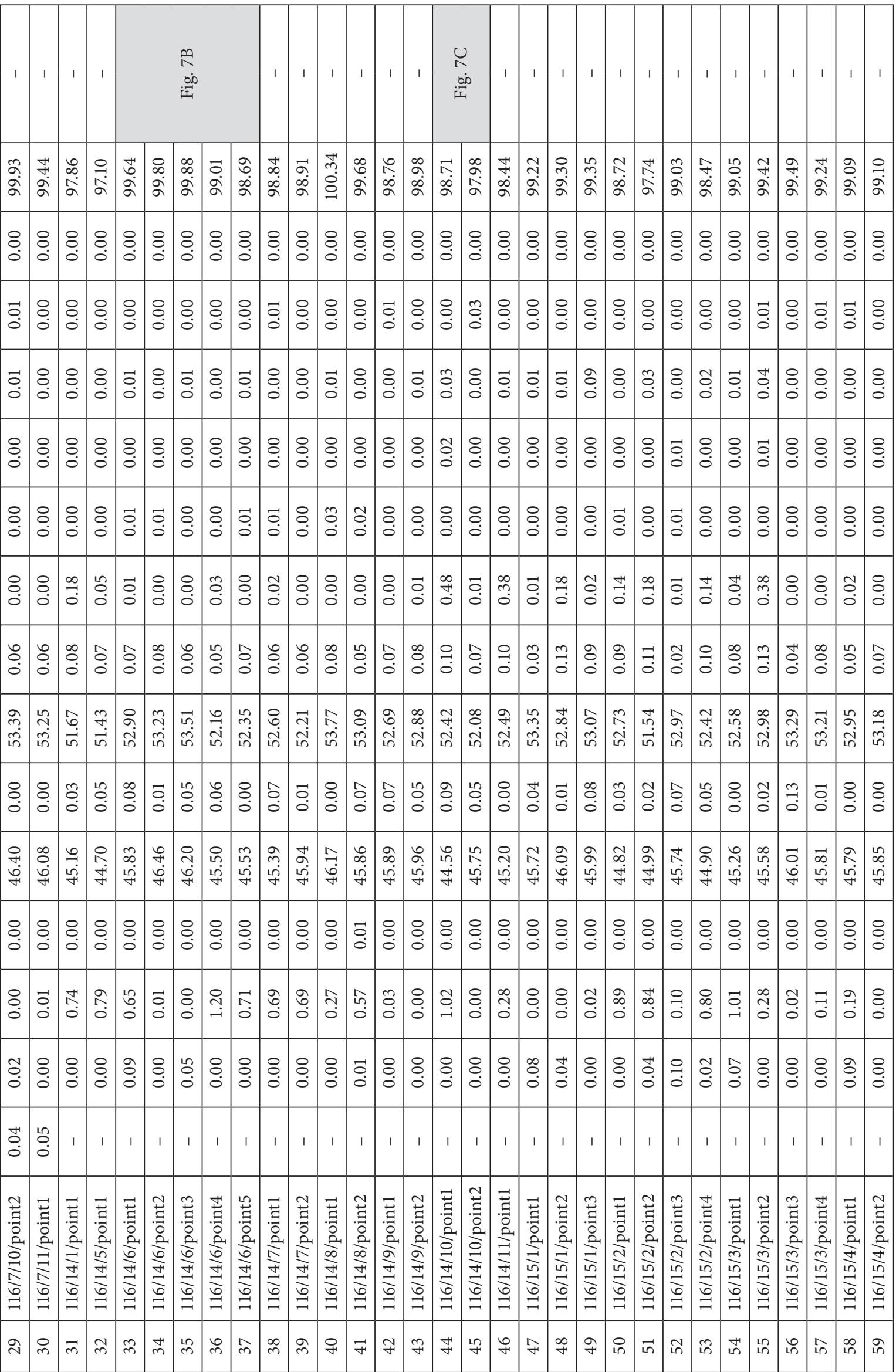




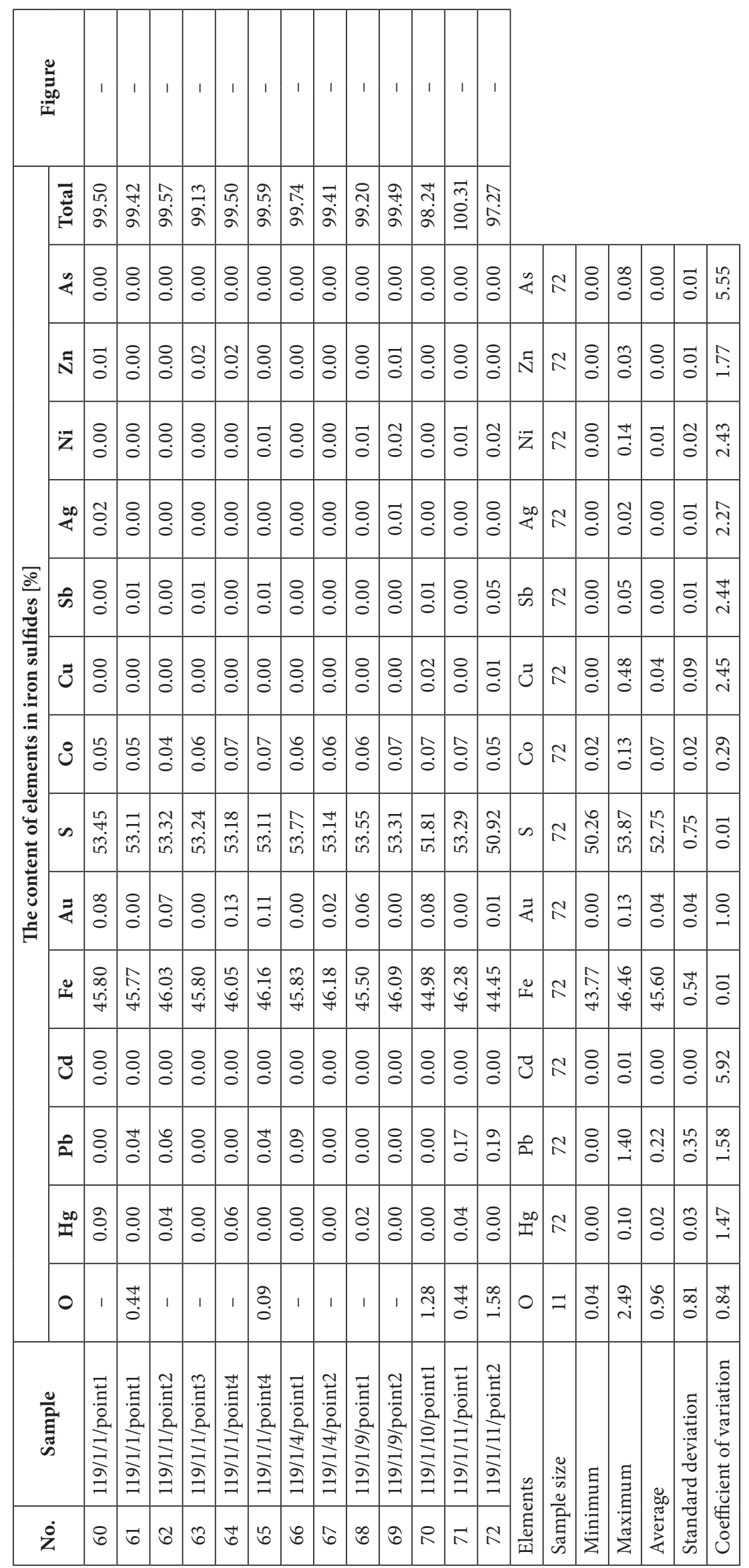


Lead, reaching up to $1.4 \%$ in the vein forms of pyrite and marcasite, has the highest concentration out of all admixtures in pyrite and marcasite (Tab. 2, Fig. 7A). The Clarkevalue of this element in the Earth's crust is 15 ppm (Kabata-Pendias \& Mukherjee 2007).

The average $\mathrm{Pb}$ content in vein forms is $0.25 \%$. The sulfides with high lead content are characterized by a lighter color. Framboidal pyrites generally contain less lead; its maximum value in the tested sulfides amounted to $0.19 \%$. In the study by Hower et al. (2008), lead content in pyrites also did not exceed $0.2 \%$. The study by Diehl (2004) on Alabama coals found up to $18 \mathrm{ppm} \mathrm{Pb}$ in pyrites and has not found any relationship between pyrite development and the content of $\mathrm{Pb}$.

Mercury $(\mathrm{Hg})$ is a very toxic chemical element, which is highly active chemically and biologically and variable in occurrence. Although mercury in the environment is present only in trace amounts, the large geochemical and biochemical activity makes it a serious threat to living organisms. This element highly accumulates in coal, which is the reason for its emissions during the combustion of coal-based fuel. Mercury abundance in the Earth's crust is very low, in the range of $0.02-0.06 \mathrm{ppm}$. Mastalerz et al. (2004) assumed a correlation between $\mathrm{Hg}$ and pyrite, suggesting that mercury is only partially associated with pyrite. Similar observations, suggesting that elevated mercury content has been determined in only a few pyrites, have been reported by Hower et al. (2008).

The maximum mercury content in the analyzed sulfides is $0.10 \%$, while the average content of this element is $0.02 \%$. Significant differences in mercury content depending on the pyrite and marcasite morphological type have not been shown.

Zinc $(\mathrm{Zn})$ is an important micro element essential for the proper functioning of the human body, but toxic when found in larger quantities. The Clarke value of zinc in the Earth's crust is 52-80 ppm.

The zinc content in the tested coal sulfides is very variable, and reaches a maximum of $0.03 \%$. Locally, in some deposits, $\mathrm{Zn}$ content in pyrites can reach $0.05 \%$ (Belkin \& Luo 2008).

Copper occurs in the Earth's crust at concentrations between $25-75 \mathrm{ppm}$ and has a strong affinity with sulfur. It is commonly associated with chalcopyrite, $\mathrm{FeCuS}_{2}$; sphalerite, $\mathrm{ZnS}$; pyrite, $\mathrm{FeS}$; and galena $\mathrm{PbS}$. For the sulfides in the tested coal, higher $\mathrm{Cu}$ values are observed in vein forms, reaching up to $0.48 \%$ (Fig. $7 \mathrm{C}$ ). In Lower Cambrian black shale (stone coal), Guizhou Province, China, the content of $\mathrm{Cu}$ in pyrites amounts up to 0.79\% (Belkin \& Luo 2008).

In the earth's crust, the mean $\mathrm{Ni}$ abundance has been estimated at about 20ppm. Nickel reveals both chalcophilic and siderophilic affinity. Nickel occurred only in part of the tested sulfides, regardless of the morphological type. The highest measured content was $0.14 \%$ in framboidal pyrite. In coal from the Upper Silesian Coal Basin, the nickel content in pyrites from the No. 301 seam reached up to $0.33 \%$ (Kucha \& Lipiarski 1998). Locally, at individual deposits, the nickel content can reach 1.37\% (Belkin \& Luo 2008). In the study by Hower et al. (2008), Ni, Cu, and $\mathrm{Zn}$ have also been found in some of the samples, while their concentrations ranged from low values to more than $0.01 \%$.

Cobalt is a relatively rare element, its average content in the Earth's crust amounts to 200 ppm. The cobalt content in the tested sulfides ranged from $160 \mathrm{ppm}$ to $1290 \mathrm{ppm}$. The analysis has not shown significant differences in cobalt content in different types of sulfides. In the case of coal from the Upper Silesian Coal Basin, the Co content in pyrites from the No. 301 seam amounted to $0.48 \%$ (Kucha \& Lipiarski 1998).

The geochemical characteristics of Ag are similar to those of $\mathrm{Cu}$. Silver was measured only in some of the sulfides and the maximum content amounted to $0.02 \%$. The highest value was observed in the vein forms, just as in the case of copper.

The abundance of $\mathrm{Au}$ in the Earth's crust is about $3 \mathrm{ppb}$; in the case of coal, this value amounts to $4 \mathrm{ppb}$. In the analyzed minerals, the Au content amounts up to $0.13 \mathrm{ppm}$. On average, Au content in the tested crystals is $0.04 \%$. Such $\mathrm{Au}$ contents are often found in natural pyrites (Fleet \& Mumin 1997).

Antimony ( $\mathrm{Sb}$ ) is a rare element; its average content in the Earth's crust ranges from $0.2 \mathrm{ppm}$ to $0.5 \mathrm{ppm}$. The study has shown that antimony is present only in vein sulfides, where its content reaches to $0.05 \%$. 

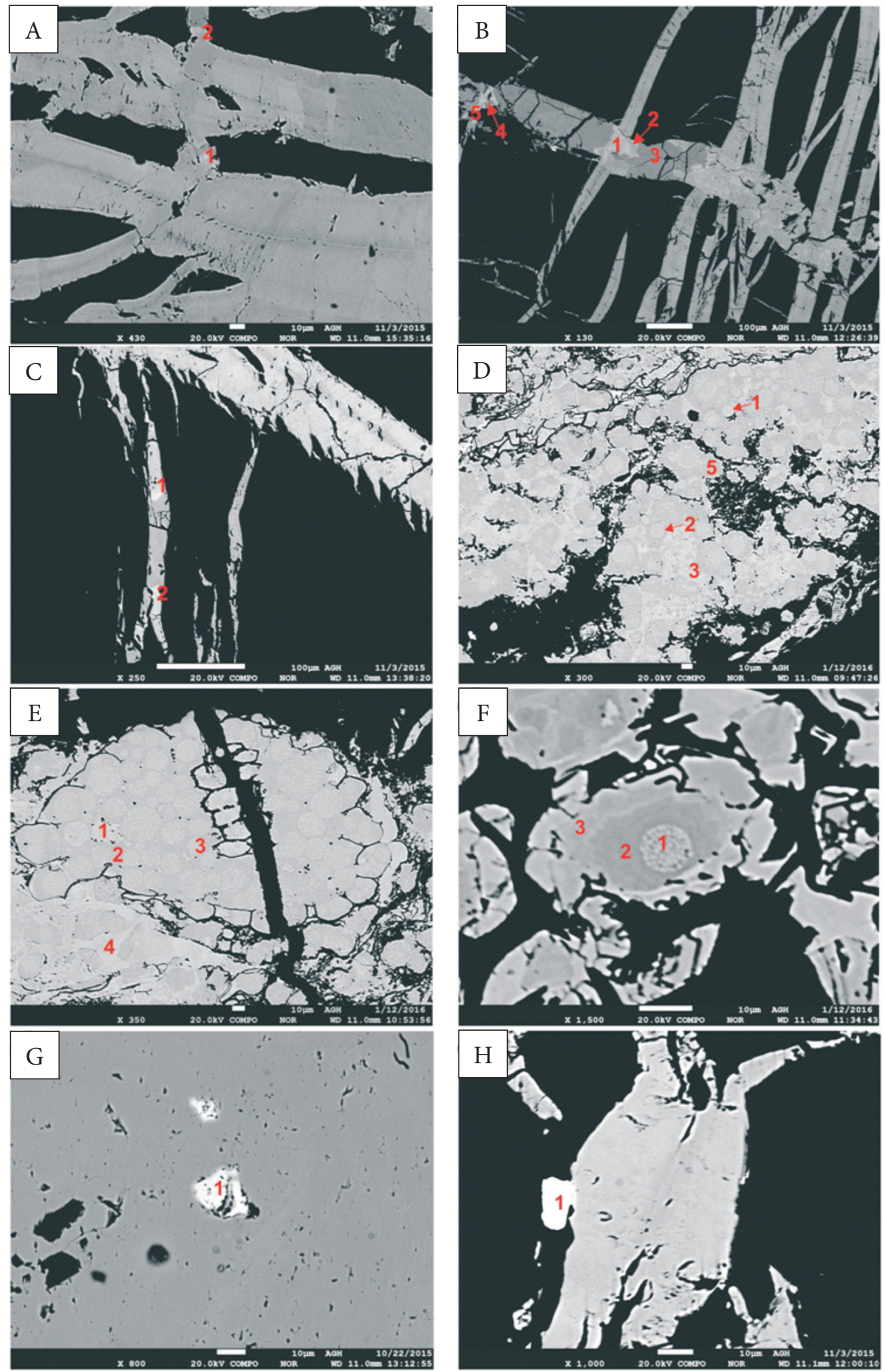

Fig. 7. The WDS (wavelength-dispersive X-ray spectroscopy) image of sulphides with the measurement points: A) iron sulfides (pyrite, marcasite) with a local lead enrichment (point 1, 2, brighter spots; sample 116/7); B) iron sulfides (pyrite, marcasite, points 2, 3) with a local lead enrichment (points 1, 4, 5, brighter spots; sample 116/14); C) iron sulfides (pyrite, marcasite) with a local lead, copper and silver (point 1) and zinc (point 2) enrichment (sample 116/14); D) polyframboids (points 1, 2, 5) with a local arsenic enrichment (point 3, sample 115/2); E) polyframboids (point 1, 2, and 3) and breccia with a binder (point 4; sample 115/2); F) iron sulphides (framboids) in fusinite cells (point 1,3), local oxygen enrichment (point 2; sample 115/2); G) iron sulfides (pyrite, marcasite) with sphalerite (point 1; sample 119/1); H) iron sulfides (pyrite, marcasite) with galena (point 1; sample 116/14). 
Arsenic is widely distributed in the environment. It occurs in the Earth's crust in the rangefrom $0.5 \mathrm{ppm}$ to $2.5 \mathrm{ppm}$. No arsenic was found in the tested vein pyrites. In the framboidal pyrites, its content reaches up to $0.08 \%$ (Fig. 7D). The measured content is relatively low. Meanwhile, higher content can be observed in other deposits, including the Lost Creek deposit, where the arsenic content in pyrites is $0.65 \%$ (Diehl et al. 2004). What is more, the study by Diehl et al. (2004) suggests the dependence of pyrite concentration on the morphology of sulfides, while the highest concentrations can be observed in massive forms. However, the question of enrichment in arsenic in impregnation forms is not clear. The element distribution map of As demonstrates at least two episodes of opening and sealing of the veins by As-poor and an As-rich pyrite (Diehl et al. 2004). An electron microprobe study of a $0.04 \%$ As lithotype from the Fire Clay coal bed, eastern Kentucky by Ruppert et al. (2005), has found wide variations in the concentration of As in different Fe-sulfide morphologies.In the examined hard coal from the Janina Coal Mine, only some framboidal pyrites, believed to be syngenetic framboids, were enriched in As. Mastalerz \& Drobniak (2007) have observed pyriteAs associations in the Springfield and Danville coals, Indiana. It has been suggested that arsenic is mainly associated with pyrite, both syngenetic and epigenetic.

The WDS analysis allowed observing pyrites as impregnations of macerals characterized by zonal structure (Fig. 7F). The aforementioned structure results from variable oxygen content and arsenic admixtures, as indicated by the measurements (Tab. 2).

The increased oxygen content of the iron sulfides has also been observed by Kucha \& Lipiarski (1998) who linked this phenomenon with the oxidation of pyrite or marcasite.

Sparsely occurring sphalerite and galena are in the form of inclusions within pyrite and marcasite. Sphalerite contains up to $6.49 \%$ iron. The admixtures of $\mathrm{Fe}$ and $\mathrm{Bi}$ are also observed in galena (Tab. 3). When it comes to iron sulfides in the vicinity of the crystallized galena, no lead $(\mathrm{Pb})$ in pyrites can be observed.

Table 3

The chemical composition of galena and sphalerite determined by WDS analysis

\begin{tabular}{|c|c|c|c|c|c|c|c|c|c|c|c|c|c|c|}
\hline \multicolumn{15}{|c|}{ The content of elements in sphalerite [\%] } \\
\hline Sample & Cd & In & $\mathrm{Zn}$ & $\mathrm{Cu}$ & $\mathbf{S}$ & Sn & $\mathrm{Hg}$ & $\mathrm{Fe}$ & Mn & Ag & Ga & Ge & Total & Figure \\
\hline 119/1/6/point1 & 0.00 & 0.00 & 62.93 & 0.00 & 32.47 & 0.00 & 0.01 & 3.28 & 0.00 & 0.00 & 0.00 & 0.00 & 98.70 & $\begin{array}{l}\text { Fig. } \\
7 \mathrm{G}\end{array}$ \\
\hline 119/1/7/point1 & 0.03 & 0.02 & 60.08 & 0.00 & 34.89 & 0.00 & 0.00 & 6.49 & 0.00 & 0.00 & 0.00 & 0.00 & 101.51 & - \\
\hline \multicolumn{15}{|c|}{ The content of elements in galena [\%] } \\
\hline Sample & $\mathrm{Te}$ & $\mathbf{P b}$ & $\mathbf{B i}$ & $S$ & $\mathrm{Cu}$ & $\mathrm{Fe}$ & Sb & Ag & $\mathrm{Se}$ & Total & Figure & & & \\
\hline $\begin{array}{l}116 / 14 / 4 / \\
\text { point1 }\end{array}$ & 0.04 & 88.2 & 0.74 & 13.78 & 0.00 & 1.38 & 0.00 & 0.08 & 0.00 & 104.23 & $\begin{array}{l}\text { Fig. } \\
7 \mathrm{H}\end{array}$ & & & \\
\hline
\end{tabular}

\section{CONCLUSIONS}

Macroscopically, iron sulfides (pyrite, marcasite) found in hard coal seams are usually in vein and pocket-like (impregnation) forms. Usually, veins occur in skeletal forms, which means that they undergo numerous fissions. Massive forms occur less frequently. While thicker than skeletal forms and their surroundings, they are not accompanied by thin veins. Pocket-like forms are impregnations of iron sulfides within fusain. The aggregates of framboidal pyrite are visible macroscopically in the case of high concentrations, usually in the form of polyframboidal aggregates.

On the basis of microscopic observations, the following forms of the occurrence of iron sulfides in the studied coal have been observed. Framboidal pyrite occurs relatively rarely. Single framboids or their concentrations, often forming polyframboidal aggregates, have been observed. Framboids in the tested coal seams have been found only in a few sections of a few centimeters length, where 
the petrographic composition of coal has revealed the occurrence of alginite, an indicator of the reducing environment. This pyrite is probably syngenetic. Epigenetic iron sulfides occur in the vein form, filling the fissures in coal, or in impregnation forms, which usually are associated with positions of fusinite occurrence; sporadically, they occur as impregnations around macrosporinite, in funginite and binding coal breccia in the fissures.

The WDS analysis in the micro area has shown different generations of iron sulfides. The analysis has shown that the sulfides occurring in the tested coal are mainly pyrite or marcasite. Their composition is similar regardless of morphological formation. However, no significant admixtures other than iron and sulfur have been observed in both pyrite and marcasite. Locally, the $\mathrm{Pb}$ content exceeds $1 \%$ in the tested samples, usually in the case of vein forms. When it comes to impregnation forms, the zonal change in the oxygen content, which may result from the oxidation of framboidal pyrite, has been observed. In addition to the iron sulfides, individual inclusions of galena and sphalerite within the pyrite and marcasite have been observed.

The work was conducted under Statutory Research No. 11.11.140.320.

The authors would like to thank MSc. Gabriela Kozub-Budzyn and MSc. Adam Gawet for carrying out the analysis.

\section{REFERENCES}

Adamczyk Z., Białecka B., Moszko J.C., Komorek J. \& Lewandowska M., 2015. Rare Earth Elements of Orzeskie Beds of South-West Part Upper Silesian Coal Basin (Poland). Archives of Mining Sciences, 60, 1, 157-172.

Balme B.E., 1956. Inorganic sulfur in some Australian coals. Fuel, 29, 21-22.

Baruah M.K., 1995. The theory of genesis of secondary sulfur. Fuel Processing Technology, 45, 155-160.

Belkin H.E. \& Luo K., 2008. Late-stage sulfides and sulfarsenides in Lower Cambrian black shale (stone coal) from the Huangjiawan mine, Guizhou Province. People's Republic of China Mineralogy and Petrology, 92, 321-340.

Bielowicz B., 2013. Selected harmful elements in Polish lignite. Gospodarka Surowcami Mineralnymi - Mineral Resources Management, 29, 3, 47-59.

Casagrande D.J., Siefert L., Berschinski C. \& Sutton N., 1977. Sulfur in peat forming systems of Okefenokee swamp and Florida Everglades, origin of sulfur in coal. Geochimica et Cosmochimica Acta, 41, 161-167.
Chou C.L., 2012. Sulfur in coals, a review of geochemistry and origins. International Journal of Coal Geology, 100, $1-13$.

Dai S., Hou X., Ren D. \& Tang Y., 2003. Surface analysis of pyrite in the No. 9 coal seam, Wuda Coalfield, Inner Mongolia, China, using high-resolution time-of-flight secondary ion mass-spectrometry. International Journal of Coal Geology, 55, 139-150.

Dai S., Wang X., Chen W., Li D., Chou C.L., Zhou Y., Zhu C., Li H., Zhu X., Xing Y., Zhang W. \& Zou J., 2010. A highpyrite semianthracite of Late Permian age in the Songzao Coalfield, southwestern China, mineralogical and geochemical relations with underlying mafic tuffs. International Journal of Coal Geology, 83, 430-445.

Dai S., Zeng R. \& Sun Y., 2006. Enrichment of arsenic, antimony, mercury, and thallium in a Late Permian anthracite from Xingren, Guizhou, Southwest China. International Journal of Coal Geology, 66, 217-226.

Dai S., Zhou P., Ren D., Wang X., Li D. \& Zhao L., 2007. Geochemistry and mineralogy of the Late Permian coals from the Songzao Coalfield, Chongging, southwestern China. Science. China Series D-Earth Sciences, 50, 678-688.

Dembowski Z., 1972. Krakowska seria piaskowcowa Górnoślaskiego Zagłębia Węglowego. Prace Państwowego Instytutu Geologicznego, 61, PIG, Warszawa.

Demchuk T.D., 1992. Epigenetic pyrite in a low-sulfur, subbituminous coal from the central Alberta Plains. International Journal of Coal Geology, 21, 187-196.

Diehl S.F., Goldhaber M.B. \& Hatch J.R., 2004. Modes of occurrence of mercury and other trace elements in coals from the warrior field, Black Warrior Basin, Northwestern Alabama. International Journal of Coal Geology, 59, 193- 208.

Diehl S.F., Goldhaber M.B., Koenig A.E., Lowers H.A. \& Ruppert L.F., 2012. Distribution of arsenic, selenium, and other trace elements in high pyrite Appalachian coals, Evidence for multiple episodes of pyrite formation. International Journal of Coal Geology, 94, 238-249.

Elswick E.R., Hower J.C., Carmo A.M., Sun T. \& Mardon S.M., 2007. Sulfur and carbon isotope geochemistry of coal and derived coal-combustion by-products, an example from an Eastern Kentucky mine and power plant. Applied Geochemistry, 22, 2065-2077.

Environment, 2015. [on-line:] http//www.stat.gov.pl [access: 31.08.2016].

Fleet M.E. \& Mumin A.H., 1997. Gold-bearing arsenian pyrite and marcasite from Carlin Trend deposits and laboratory synthesis. The American Mineralogist, 82, 182-193.

Frankie K.A. \& Hower J.C., 1987. Variation in pyrite size, form and microlithotype association in the Springfield (No. 9). and Herrin (No. 11). coals, western Kentucky. International Journal of Coal Geology, 7, 349- 364.

Górecki J., 1985. Siarka w polskich złożach węgla kamiennego. Gospodarka Surowcami Mineralnymi - Mineral Resources Management, 1, 1, 111-120.

Harvey R.D. \& DeMaris P.J., 1987. Size and maceral association of pyrite in Illinois coals and their float-sink fractions. Organic Geochemistry, 2, 343-349.

Harvey R.D. \& Ruch R.R., 1986. Mineral matter in Illinois and other US coals. [in:] Vorres K.S. (ed.), Mineral Matter in Coal Ash and Coal, American Chemical Society Symposium Series, 301, American Chemical Society, $10-40$. 
Hower J.C., Campbell J.L., Teesdale W.J., Nejedly Z. \& Robertson D., 2008. Scanning proton microprobe analysis of mercury and other trace elements in Fe-sulfides from a Kentucky coal. International Journal of Coal Geology, $75,88-92$.

ICCP, 1998. The new vitrinite classification (ICCP System 1994). Fuel, 77, 349-358.

ICCP, 2001. The new inertinite classification (ICCP System 1994). Fuel, 80, 459-471.

ICDD, 2017. International Centre for Diffraction Data Powder Diffraction File PDF-2. [on-line:] http://www.icdd. com/products/pdf2.htm [access: 21.02.2017].

Jureczka J., Aust J., Buła Z., Dopita M. \& Zdanowski A., 1995. Mapa geologiczna GZW (odkryta po karbon). Wydawnictwo Kartograficzne, Warszawa.

Kabata-Pendias A. \& Mukherjee A.B., 2007. Trace Elements from Soil to Human. Springer-Verlag, Berlin.

Ketris M.P. \& Yudovich Ya.E., 2009. Estimations of Clarkes for Carbonaceous biolithes, World averages for trace element contents in black shales and coals. International Journal of Coal Geology, 78, 135-148.

Kokowska-Pawłowska M., 2014. Relationship Between the Content of Hazardous Trace Elements in Coal Lithotypes and their Ashes (405 Coal Seam, USCB). Gospodarka Surowcami Mineralnymi - Mineral Resources Management, 30, 2, 51-66.

Kolker A., 2012. Minor element distribution in iron disulfides in coal, A geochemical review. International Journal of Coal Geology, 94, 32-43.

Kortenski J. \& Kostova I., 1996. Occurrence and morphology of pyrite in Bulgarian coals. International Journal of Coal Geology, 29, 273-292.

Kucha H. \& Lipiarski I., 1998. Mineralogy and geochemistry of sulfides from coal seams, Upper Silesian Coal Basin, Poland. Mineralogica Polonica, 29, 2, 23-40.

Kwiecińska B.K., Hamburg G. \& Vleeskens J.M., 1992. Formation temperatures of natural coke in the Lower Silesian coal basin, Poland, evidence from pyrite and clays by SEM-EDX. International Journal of Coal Geology, 21, 217-235.

Mastalerz M. \& Drobniak A., 2007. Arsenic, cadmium, lead, and zinc in the Danville and Springfield coal members (Pennsylvanian). from Indiana. International Journal of Coal Geology, 71, 37-53.

Mastalerz M., Hower J.C., Drobniak A., Mardon S.M. \& Lis G., 2004. From in-situ coal to fly ash, a study of coal mines and power plants from Indiana. International Journal of Coal Geology, 59, 171-192.

Misiak J., 2011. Microlithotype profile of the coal seam no. 116/2 (Libiąż beds). with facial interpretation - ZG "Janina" (USCB). Gospodarka Surowcami Mineralnymi - Mineral Resources Management, 27, 2, 5-15.

Querol X., Chinchon S. \& Soler A.L., 1989. Iron sulfide precipitation sequence in Albian coals from the Maestrazgo Basin, southeastern Iberian Range, northeastern Spain. International Journal of Coal Geology, 11, 171-189.

Renton J.J. \& Bird D. S., 1991. Association of coal macerals, sulfur, sulfur species and the iron disulfide minerals in three columns of the Pittsburgh coal. International Journal of Coal Geology, 17, 21-50.
Renton J.J. \& Cecil C.B., 1979. The origin of mineral matter in coal. [in:] Donalson A.C., Presley M.W.\& Renton J.J. (red.), Carboniferous Coal Guidebook,1, Bulletin,37, West Virginia Geological \& Economic Survey, 206-223.

Ruppert L.F., Hower J.C. \& Eble C.F., 2005. Arsenic-bearing pyrite and marcasite in the Fire Clay coal bed, Middle Pennsylvanian Breathitt formation, eastern Kentucky. International Journal of Coal Geology, 63, 27-35.

Sawłowicz Z., 2000. Framboids - from their origin to application. Prace Mineralogiczne, 9288, Wyd. Oddziału Polskiej Akademii Nauk, Kraków.

Spears D.A., Manzanares-Papayanopoulos L.I. \& Booth C.A., 1999. The distribution and origin of trace elements in a UK coal, the importance of pyrite. Fuel, 78, 16711677.

Stach E., Mackowsky M.Th., Teichmüller M., Taylor G.H., Chandra D. \& Teichmüller R., 1982. Stach's Textbook of Coal Petrology. Gebrüder Borntraeger, Stuttgart.

Taylor G.H., Teichmüller M., Davis A., Diessel C.F.K., Littke R. \& Robert P., 1998. Organic Petrology, Gebrüder Borntraeger, Berlin.

Turner B.R. \& Richardson D., 2004. Geological controls on the sulfur content of coal seams in the Northumberland Coalfield, Northeast England. International Journal of Coal Geology, 60, 169-196.

UNECE, 1998. International Classification of In-Seam Coals.Symbol Number: ENERGY/1998/19. [on-line:] http://www.unece.org/energy/se/coal/code.html [access: 24.06.2016]

United Nations, 2015. Adoption of the Paris agreement. FCCC/CP/2015/L.9/Rev.1, Conference of the Parties Twenty-first session, Paris, 30 November to 11 December 2015.

Uytenbogaardt W. \& Burke E.A.J., 1985. Tables for microscopic identification of ore minerals. Dover Publications.

Ward C.R., 2002. Analysis and significance of mineral matter in coal seams. International Journal of Coal Geology, 50, 135-168.

Weise R.G., Muir I.J. \& Fyfe W.S., 1990. Trace-element siting in iron sulfides in Ohio coals determined by secondary ion mass spectrometry (SIMS). International Journal of Coal Geology, 14, 155-174.

Widodo S., Oschmann W., Bechtel A., Sachsenhofer R.F., Anggayana K. \& Puettmann W., 2010. Distribution of sulfur and pyrite in coal seams from Kutai Basin (East Kalimantan, Indonesia), Implications for paleoenvironmental conditions. International Journal of Coal Geology, 81, 151-162.

Wiese R.G. \& Fyfe W.S., 1986. Occurrences of iron sulfides in Ohio coals. International Journal of Coal Geology, 6, 251-276.

Wilkin R.T. \& Barnes H.L., 1997. Formation processes of framboidal pyrite. Geochimica et Cosmochimica Acta, 61, 323-339.

Yudovich Y.E. \& Ketris M.P., 2005. Arsenic in coal, a review. International Journal of Coal Geology, 61, 141-196.

Zdanowski A. \& Żakowa H., 1995. The Carboniferous system in Poland. Prace Państwowego Instytutu Geologicznego, 148, PIG, Warszawa. 